\title{
Expanding access to education for teenage mothers in Homa Bay County: What 'might' work
}

Chi-Chi Undie

Population Council

Follow this and additional works at: https://knowledgecommons.popcouncil.org/departments_sbsr-rh

Part of the Education Policy Commons, Health Policy Commons, International Public Health Commons, Maternal and Child Health Commons, and the Women's Health Commons How does access to this work benefit you? Let us know!

\section{Recommended Citation}

Undie, Chi-Chi. 2015. "Expanding access to education for teenage mothers in Homa Bay County: What 'might' work," presentation at APHRC Roundtable Discussion: "What Works for Girls' Education," Nairobi, Kenya. 


\section{Expanding Access to Education for Teenage Mothers in Homa Bay County}

\section{What 'Might' Work}

\section{Chi-Chi Undie, Population Council} APHRC Roundtable Discussion What Works for Girls' Education October 9, 2015; Nairobi, Kenya

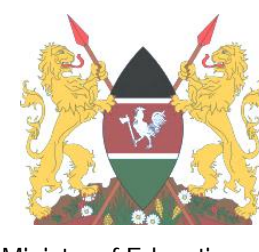

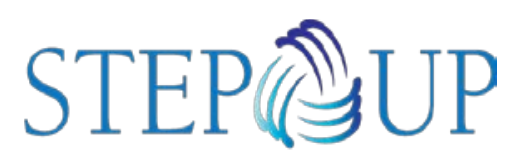

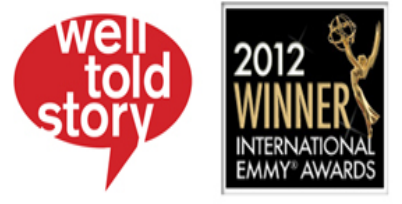

POPULATION
COUNCIL
Ideas. Evidence. Impact. 


\section{Context}




\section{Homa Bay County Context}

$40 \%$ of girls aged $15-$

19 have begun childbearing
More than $2 x$ the national level of

$18 \%$

Few ever

return to

school

Of these, $9 \%$ had a

live birth before age

15
$17 \%$ of women aged 15-49 are married before age 15 


\section{Kenyan policy context}

\section{4}

- Adoption of school reentry policy for girls. Guidelines formulated in 1996.

\section{7}

- Adoption of Gender Policy in Education with reference to school reentry for student mothers

\section{8}

- Free Secondary Education policy passed. Tuition covered in public, day schools.

\section{9}

- Publication

of

National

School

Health

Policy,

including guidance on

handling in-school pregnancy 


\section{Community context}

\section{Out-of-school teen girls in Homa Bay $(n=728)$}

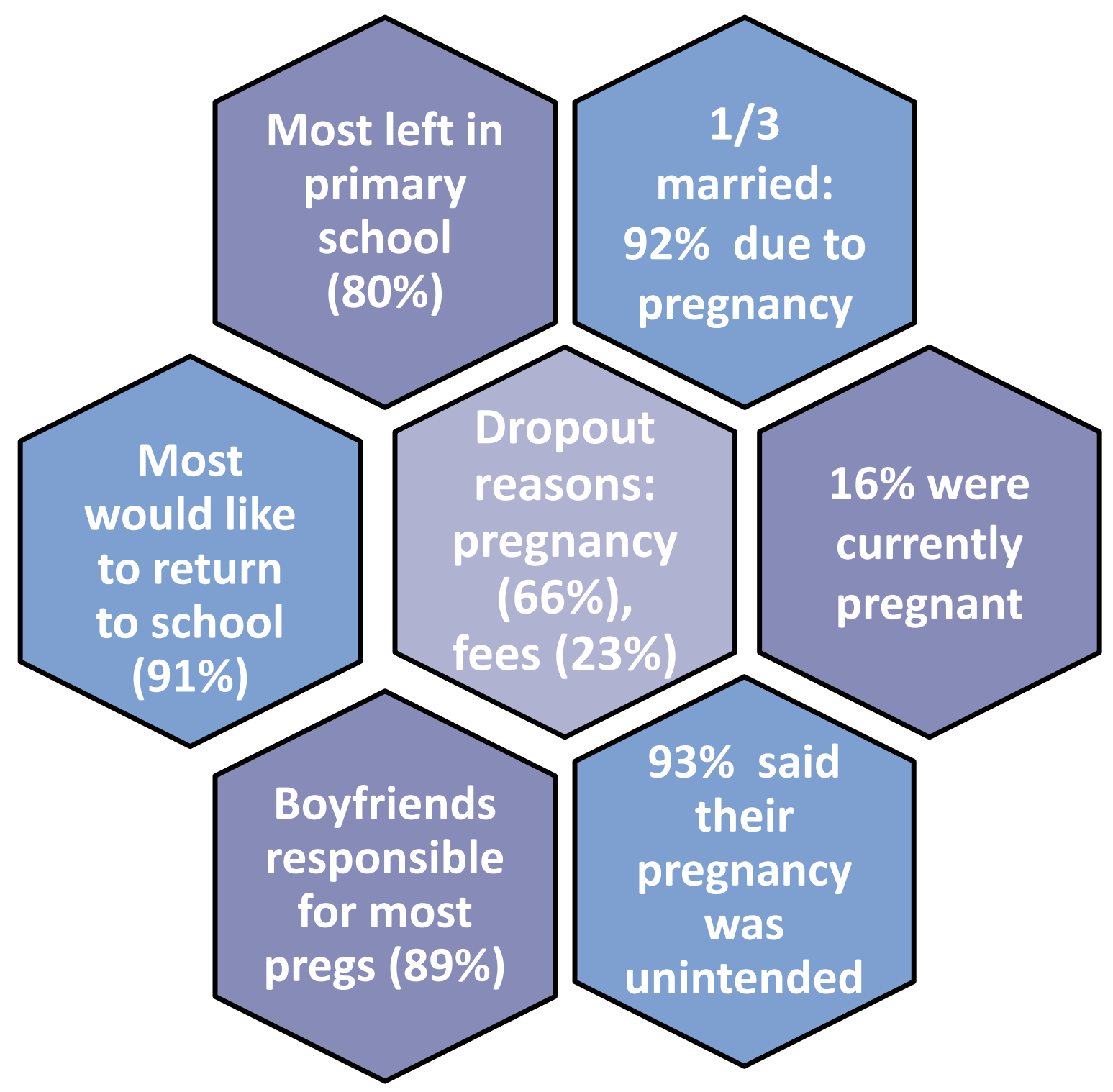




\section{Awareness: Had not heard of ...}

Policy*

Out-ofschool girls Heads

$$
\text { ( } n=728 \text { ) }
$$

$7 \%$

Entry

National

School Health
$36 \%$
Household School

$(n=511)$

$11 \%$

$35 \%$

$2 \%$
Free

Secondary

Education
Principals

( $n=167)$

$18 \%$
$\mathrm{n} / \mathrm{a}$
$57 \%$
$55 \%$ 
What's the best model? 


\section{Policy dialogue and advocacy}

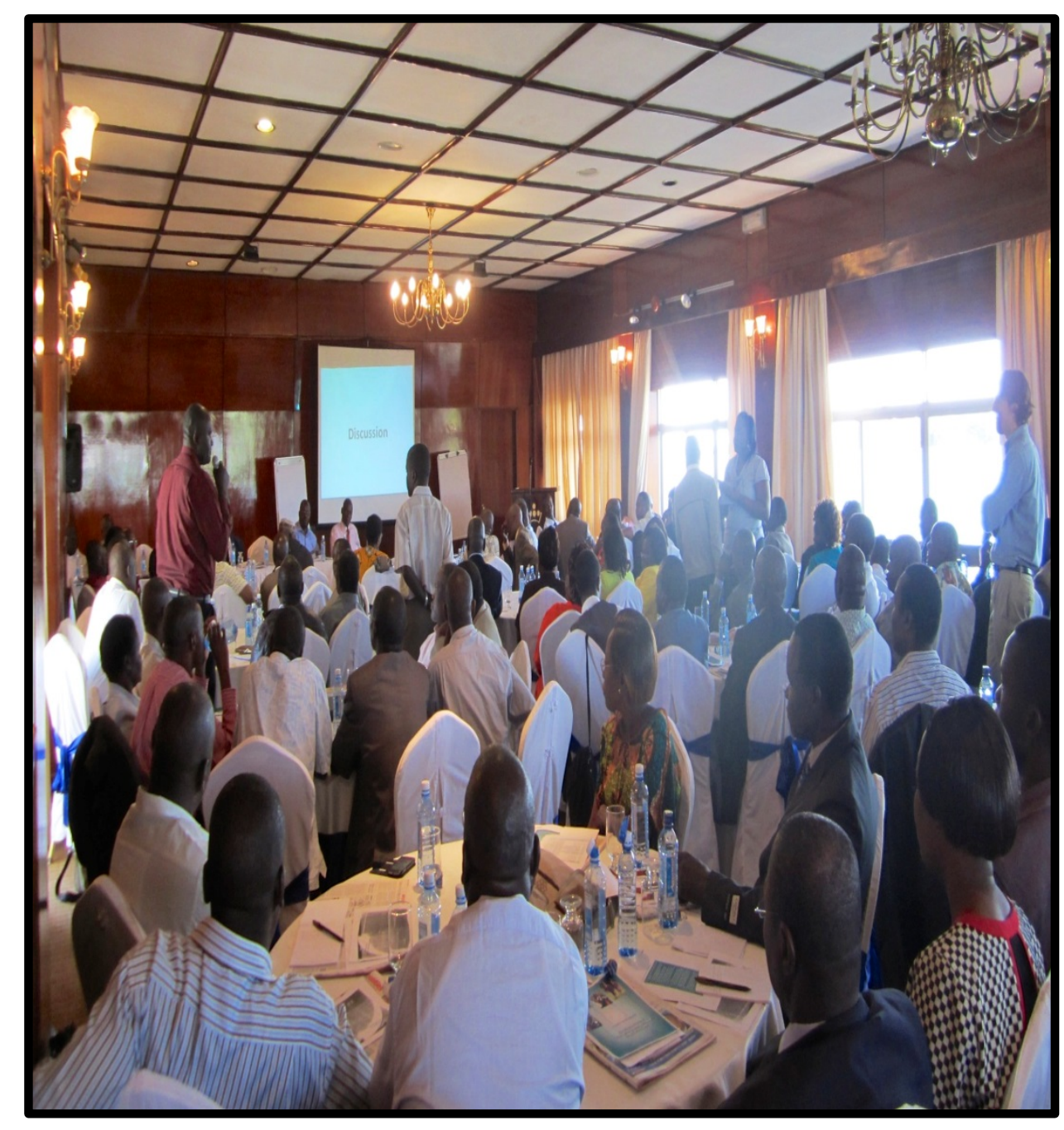

- Two dialogues

- 200 school principals from schools in the study sites

- Advocacy with Homa Bay County Dept of Education 


\section{Interactive media campaign}

- 'Real-life' radio series

- Expert interviews (MOE, principals, community leaders, etc.) on policies

- Call-ins, prizes

- Complementary IEC materials on policies

- Road shows

- Engagement of local celebrity \& politicians (Women's rep, etc.)
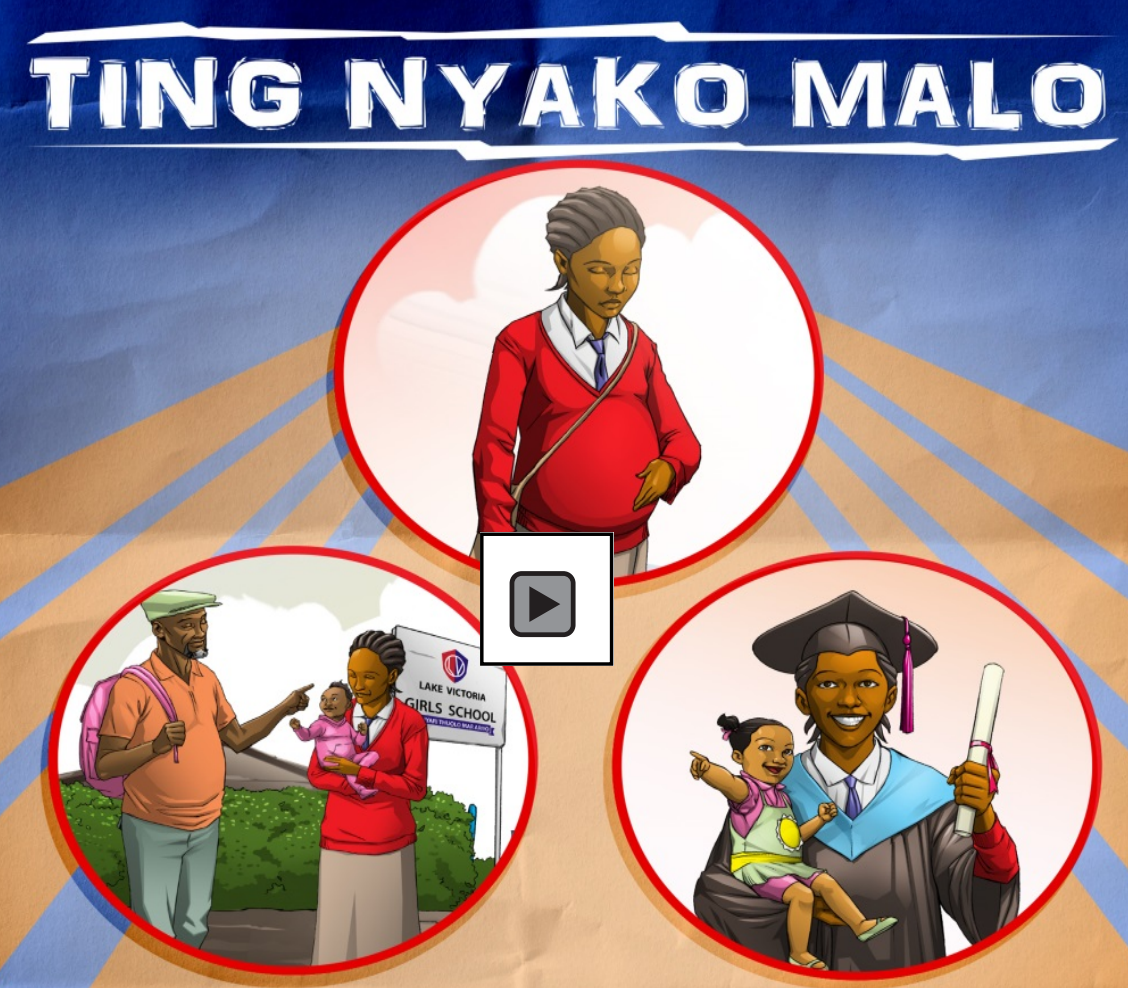

"MI NYARI THUOLO MAR ARIYO"

RADIO LAKE VICTORIA 92.1 FM FRIDAY 7 PM RLY F2.1FM POPULATION

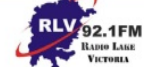
EDUCATION Ideas. Evidence. Im 


\section{Lessons learned from implementation}




\section{What we're learning}

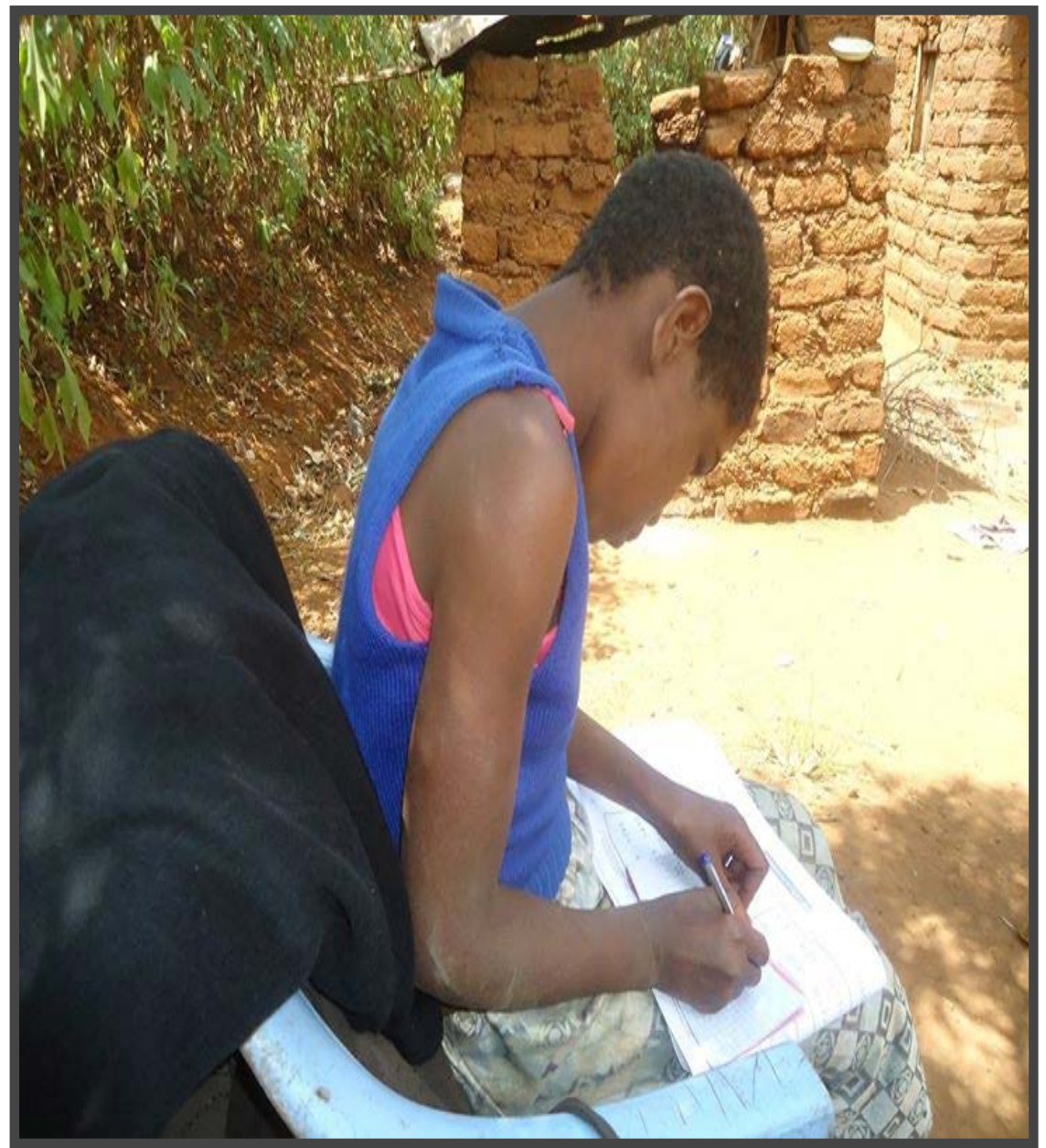

- Dialogue is critical

- Schools aren't the enemy

- Schools face important constraints

- Schools want to help

- Initial support for stakeholders is important

- Girls want to return to school (married and unmarried) 


\section{What 'might' work}

$\checkmark$ Leaving pre-conceived notions behind

o Being bold, asking tough questions, no such thing as 'no-go' areas

$\checkmark$ Listening

$\checkmark$ Working collaboratively with a view toward letting go 


\section{Thank you}

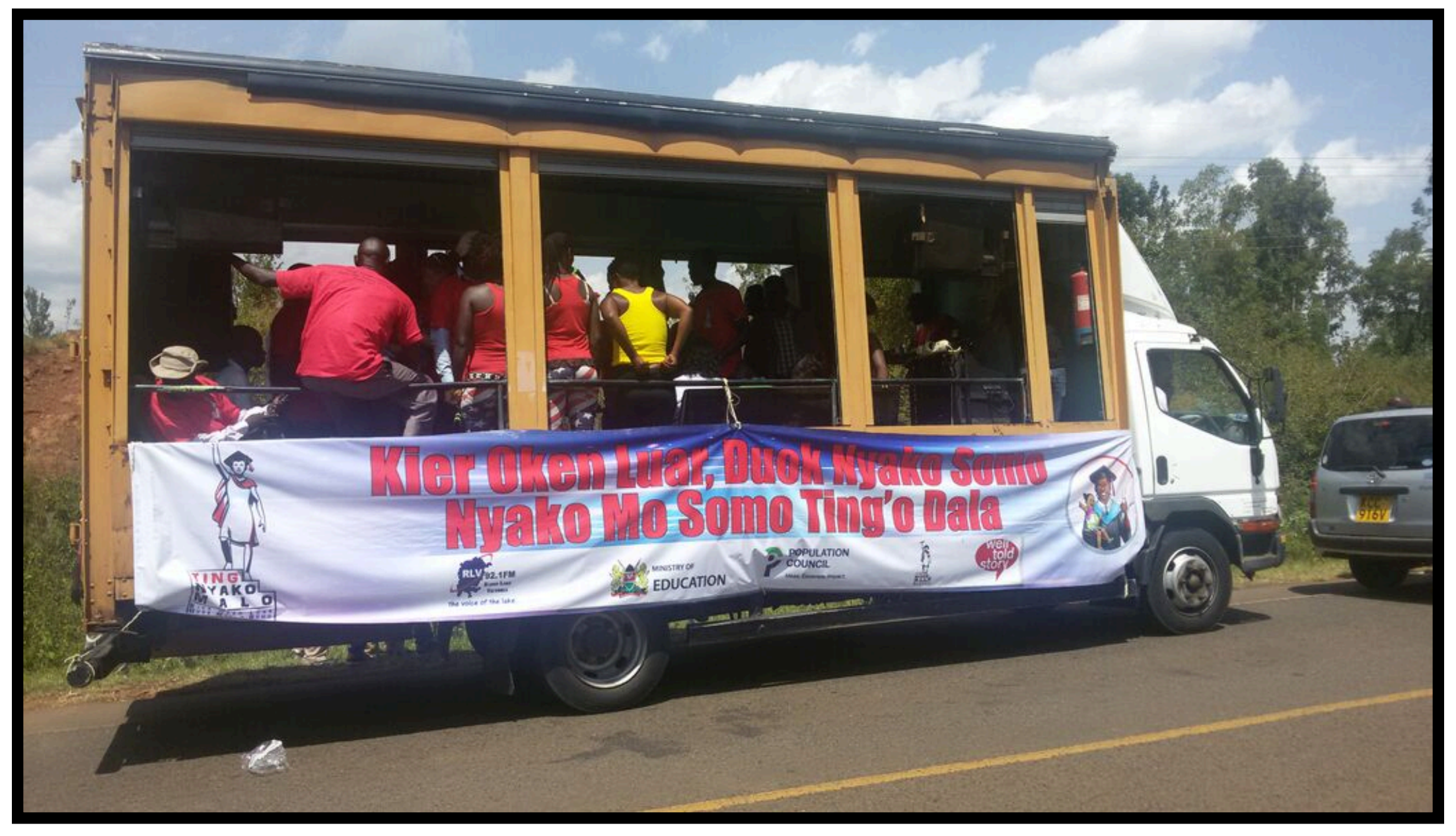




\section{Acknowledgment}

- Cover slide photo courtesy of gdstone (http://www.flickr.com/people/gdstone/). 


\section{The}

Population Council conducts biomedical, social science, and public health research. We deliver solutions that lead to more effective policies, programs, and technologies that improve lives around the world. 